Gulawentah: Jurnal Studi Sosial

ISSN 2528-6293 (Print); ISSN 2528-6871 (Online)

Vol. 5, No. 2, Desember 2020, Hal 125-131

Tersedia Online: http://e-journal.unipma.ac.id/index.php/gulawentah

\title{
Nilai-nilai Sejarah Berbasis Local Wisdom Situs Batu Berak Sebagai Sumber
} Pembelajaran Sejarah

\author{
Muhammad Basri*, Suparman Arif, Yusuf Perdana dan S Sumargono \\ Program Studi Pendidikan Sejarah, Universitas Lampung, Jl. Prof. Sumantri Brojonegoro No 1 \\ Bandar Lampung, Indonesia \\ Email: muhammad.basri@ fkip.unila.ac.id*; suparman.arif@fkip.unila.ac.id; \\ yusuf.perdana@fkip.unila.ac.id; sumargono.1988@fkip.unila.ac.id
}

\begin{abstract}
Abstrak
Penelitian ini bertujuan untuk mengkaji nilai-nilai sejarah yang berbasis local wisdom situs Batu Berak sebagai sumber pembelajaran sejarah. Lokasi Situs Batu Berak terletak di Pekon Pura Jaya, Kecamatan Kebun Tebu, Kabupaten Lampung Barat, Provinsi Lampung. Penelitian ini merupakan penelitian ualitatif dengan pendekatan deskriptif. Teknik pengumpulan data melalui observasi, wawancara, dan dokumentasi. Teknik keabsahan data menggunakan triangulasi sumber, untuk analisis data menggunakan analisis model interaktif. Situs Batu Berak merupakan Situs bersejarah masa animisme yang dilindungi oleh Badan pelestarian Cagar Budaya. Sebagai sumber pembelajaran sejarah Situs Batu Berak memiliki Nilai - nilai Sejarah yang dapat dijadikan optimalisasi materi pembelajaran sejarah indonesia, khususnya masa praaksara dengan mengenal lebih dalam kebudayaan zaman batu. Situs Batu Berak sebagai sumber pembelajaran sejarah dapat memotivasi peserta didik dalam proses pembelajaran. selain hal tersebut, juga dapat menjadikan peserta didik untuk belajar sejarah melalui living history yakni belajar sejarah dari lingkungan sekitar. Situs Batu Berak juga berpot ensi untuk para peserta didik untuk turut serta merawat dan melestarikan peninggalan - peninggalan bersejarah yang berada di sekitarnya.
\end{abstract}

Kata kunci: situs Batu Berak; local wisdom; sumber belajar

\section{Historical Values Based on Local Wisdom of Batu Berak Site as Historical Learning Resources}

\begin{abstract}
This paper aims to examine the historical values based on Batu Berak Sites as a historical learning resource. The sites is located in Pekon Pura Jaya, Kebun Tebu District, West Lampung Regency, Lampung Province. This research used qualitative approach, data collecting by direct observation, interview and documentation. The research used triangulation to examine the validity and using interactive model analysis for data analysis. Batu Berak Site is a historic site that is protected by the Cultural Heritage Conservation Agency. As a source of historical learning the sites has historical values that can be made to optimize the learning material of Indonesian history, specially he prehistoric period with deeper knowledge in stone age culture. Batu Berak Site as a source of historical learning can motivate the students in the learning process. Beside this, students can also do to learn history through life history by visiting the sites. The Batu Berak site also helps tudents participate in caring for and preserving historical relics.
\end{abstract}

Keywords: Batu Berak site, local wisdom; learning resources

DOI: 10.25273 /gulawentah.v5i2.7241

Some rights reserved. 


\section{Pendahuluan}

Kerajaan Sekala Brak dianggap sebagai cikal bakal masyarakat Lampung. Kerajaan Sekala Brak merupakan kerajaan yang pada awalnya berdirinya terletak di Dataran Belalau yang keberadaannya di sekitar Danau ranau, yang sekarang termasuk di dalam wilayah Kabupaten Lampung Barat (Siska, 2017 : 177). Salah satu peninggalan dari Kerajaan Sekala Brak adalah Situs Megalitik Batu Berak yang terletak di Pekon Purajaya, Kecamatan Kebun Tebu, Lampung Barat atau lebih tepatnya berada di kawasan Taman Nasional Bukit Barisan Selatan. Situs batu berak merupakan situs bersejarah yang dilindungi oleh pemerintah berdasarkan UU No. 11 tahun 2010 pasal 1 butir 1 menjelaskan bahwa Cagar budaya merupakan warisan budaya bersifat kebendaan berupa benda cagar budaya, bangunan cagar budaya, struktur cagar budaya, situs cagar budaya, dan kawasan cagar budaya di darat dan atau di air yang perlu dilestarikan keberadannya, karena memiliki nilai penting bagi sejarah, ilmu pengetahuan, pendidikan, agama, dan atau kebudayaan melalui proses penetapan (UU No. 11 tahun 2010 pasal 1 butir 1).

Situs Megalitik Batu Berak mempunyai beberapa Nilai. Nilai sendiri merupakan sesuatu yang dipentingkan manusia sebagai subjek. Nilai- nilai tersebut dalam sejarah memiliki peranan penting bagi dunia pendidikan khususnya persekolahan. Pelajaran sejarah menjadi media dalam menyampaikan arti pentingnya peninggalan sejarah sebagai sebuah warisan leluhur. Pendidikan sejarah yang kesannya hanya berhayal atau berhalusinasi dapat di empiriskan atau di faktakan dengan adanya situs- situs cagar budaya yang ada disekitar kita. Pentingnya pelajaran sejarah di sekolah merupakan hal yang sangat fundamental. Mata pelajaran Sejarah memiliki arti strategis dalam pembentukan watak dan peradaban bangsa yang bermartabat serta dalam pembentukan manusia Indonesia yang memiliki rasa kebangsaan dan cinta tanah air. Bangsa yang tidak mengenal sejarahnya dapat diibaratkan seorang individu yang telah kehilangan memorinya, ialah orang yang pikun atau sakit jiwa, maka dia kehilangan kepribadian atau identitasnya (Kartodirjo, $1993: 50$ ).

Nilai- nilai sejarah terhadap peninggalan sejarah perlu di pelajari, karena nilai-nilai tersebut merupakan aset berharga yang mungkin tidak dimiliki oleh wilayah lain bahkan negara lain. Penemuan nilai-nilai sejarah yang terdapat pada situs bersejarah diharapkan juga dapat menambah wawasan pengetahuan edukasi bagi siswa-siswa di tingkat persekolahan. Seperti yang terjadi dalam pembelajaran sejarah di sekolah, bahwa diantara tujuan pendidikan yaitu kepribadian atau pembentukan watak. Mempelajari sejarah akan memperoleh empat kegunaan, yaitu guna rekreatif, guna inspiratif, guna instruktif, dan guna edukatif. Lebih lanjut, peristiwa masa lampau yang diangkat kembali melalui prosedur penelitian sejarah oleh ahli dianggap memiliki manfaat atau kegunaan bagi kehidupan manusia pada masa sekarang yang mempelajarinya, antara lain untuk pendidikan, memberi pengajaran (instruktif), memberi ilham (inspiratif), memberi kesenangan (rekreatif) (Wasino, $2007: 10$ ).

Kartodirjo (2014:2) menjelaskan bahwa kesadaran akan nilai-nilai sejarah terhadap sesuatu mengandung arti sadar akan apa yang diamati dan sadar terhadap proses pengamatanya. Pengetahuan sejarah yang harus dimiliki siswa adalah peristiwa-peristiwa sejarah masa prasejarah hingga sekarang, baik itu sejarah di Indonesia maupun dunia. Pendapat lain dari L.B Namier dalam Soedjatmoko (1995 : 368) bahwa, tujuan dari pendekatan historis adalah untuk memahami situasi-situasi, untuk mengkaji kecenderungan-kecenderungan, untuk mengetahui bagaimana sejumlah hal berjalan dan puncak pencapaian studi sejarah adalah kesadaran sejarah yang memuat suatu pemahaman intuitif mengenai bagaimana sejumlah hal tidak terjadi (bagaimana sejumlah hal terjadi merupakan masalah pengetahuan khusus). Sumber belajar sejarah sendiri berbasis local wisdom dapat memotivasi siswa dan motivasinya untuk ingin lebih mengetahui tentang sejarah (Prananda, Sarkadi, \& Ibrahim, 2018 : 78). Nilai - nilai Sejarah berbasis local wisdom diperlukan dalam pembelajaran sejarah lokal, khususnya sejarah lokal Lampung yang memiliki banyak kearifan lokal. Salah satu local wisdom di lampung yang dapat dimanfaatkan sebagai sumber pembelajaran sejarah adalah Situs Batu Brak. 


\section{Metode Penelitian}

Penelitian ini menggunakan metode kualitatif dengan pendekatan deskriptif. Penelitian kualitatif adalah rangkaian kegiatan atau proses menjaring data yang bersifat sewajarnya mengenai suatu masalah dalam kondisi atau aspek kehidupan tertentu pada objeknya (Nazir,1998 : 57). Miles \& Huberman menjelaskan dalam penelitian kualitatif data yang muncul dengan wujud kata-kata dan bukan rangkaian angka-angka. Data itu mungkin telah dikumpulkan dalam aneka macam cara (observasi, wawancara, intisari dokumen, pita rekaman), dan biasanya diproses kira-kira sebelum siap digunakan melalui pencatatan, pengetikan, penyuntingan atau alih tulis, tetapi analisis kualitatif tetap menggunakan kata-kata, yang biasanya disusun ke dalam teks yang diperluas (Miles \& Huberman dalam Sri Ekwandari, Perdana, \& Lestari, 2020 : 20) .

Beberapa Tahapan penelitian adalah sebagai berikut : Reduksi data yakni dengan mengklasifikasikan data dari hasil wawancara mendalam, observasi, dan dokumentasi. Penyajian data dilakukan setelah reduksi data, yang tersaji dalam bentuk teks bersifat deskriptif. Proses selanjutnya adalah penarikan kesimpulan atau verifikasi yang dilakukan dengan melihat makna hubungan-hubungan data yang diperoleh dari hasilobsevarsi, wawancara mendalam, serta dokumentasi (Perdana, Sumargono, \& Rachmedita, 2019 : 87).

\section{Hasil dan Pembahasan}

\section{Nilai-nilai Sejarah berbasis Local Wisdom Situs Batu Brak}

Kaitannya dengan nilai sejarahnya, dapat dikaitkan dengan proses penyebaran masyarakat pada masa itu di Pulau Sumatra. Menurut keterangan dari Dinas Pendidikan Subdin Kebudayaan Provinsi Lampung dan penjaga situs diperoleh bahwa situs ini merupakan situs pada masa peradaban megalitikum dan diasumsikan situs tersebut adalah situs pemukiman dan pemujaan yang telah mengenal bercocok tanam.

Arsip dan Dokumentasi Museum Lampung bahwa situs Batu Berak merupakan situs lanjutan dari proses penyebaran masyarakat pada masa itu yang berawal dari Palas Pasemah, Sumatra Selatan yang kemudian terus menyebar keseluruh daerah pesisir dan pedalaman daerah Lampung. Menurut Geldern dalam (Abdulah, Lapian, \& Dkk, 2012 : 310) menyatakan bahwa kebudayaan megalitik yang masuk Ke Indonesia dapat di bagi dalam dua gelombang. Gelombang pertama terjadi pada zaman Neolitik Akhir sekitar Tahun 2.500-1.500 SM yang masuk ke Indonesia dibawa oleh imigran Tonkin menuju Malaysia Barat dan ke Sumatra berlajut ke Jawa, Nusa Tenggara, dan menyebar di Kalimantan. Gelombang selanjutnya masuk pada masa perunggu dan besi awal dengan kebudayaan Dongson pada abad IV-III SM yang disebut dengan kebudayaan megalitik muda. Lebih lanjut, penyebaran megalitik di Sumatra ditemukan di sekitar Pulau Samosir, Nias, Limapuluh Koto, Kerinci, Lahat, Lampung Utara, Lampung Tengah, dan Lampung Selatan (Schnitger, dalam Abdulah et al., 2012 :311). Selain itu, menurut Hoop bahwa komunitas megalitik Pasemah berpusat di dataran tinggi Pasemah yang sekarang menjadi wilayah Lahat dan Pagar Alam dengan temuan menhir, dolmen, lesung batu, dan blik batu. Dari uraian di atas, maka dapat di analisis bahwa situs Batu Berak merupakan peradaban masyarakat megalitik yang termasuk awal masuk ke Indonesia.

Situs megalitik batu berak ini pertama kali diketemukan pada Tahun 1951 oleh BRN (Badan Rekonstruksi Nasional). Penelitian pertama dimulai pada tahun 1980 oleh Prof.Dr.Aris Soekandar seorang arkeolog dari Jakarta. Komplek situs megalitik Batu 
Berak ini berada dibawah naungan Dinas Kebudayaan dan Pariwisata Provinsi Lampung yang bekerjasama dengan Badan Suaka Purbakala Banten.

Situs megalitik Batu Berak ini dahulu dipakai sebagi tempat pemujaan, bukan tempat pemakaman pada zaman animisme. Situs ini telah melalui pemugaran selama empat tahap, yang dimulai pada tahun 1984 hingga 1989. Pada tahun 1989, komplek situs megalitik batu berak ini mulai dibuka untuk umum baik untuk wisata maupun untuk keperluan penelitian. Terdapat beberapa jenis batu didalam komplek situs megalitik batu berak ini, antara lain :

1. Batu tegak

Berjumlah 40 buah, berbahan batu andesed, dan berfungsi sebagai tempat mengikat hewan pada waktu upacaran keagamaan pada masa animisme.

2. Dolmen atau meja

Berjumlah 38 buah, berbahan batu moneled, dan berfungsi sebagai tempat menaruh sesajen pada waktu upacara keagamaan masa animisme.

3. Batu datar

Berjumlah 3 buah, bahan dari batu ini masih dalam proses penelitian, sedangkan fungsi nya sama dengan dolmen.

4. Batu umpak

Merupakan bongkahan batu kecil-kecil yang belum diketahui fungsinya.

Dari hasil penggalian disekitar komplek situs megalitik Batu Berak ditemukan beberapa benda, antara lain : Manik - manik Berbahan kaca dan batu. Pecahan keramik Baik yang berasal dari lokal maupun asing. Situs ini tidak jarang didatangi para warga lokal maupun luar desa. Situs ini memberikan suatu daya tarik tersendiri, dimana penempatan batu yang unik yang sedikit bersifat mistis tetapi mempunyai nilai seni yang tinggi, membuat situs ini menjadi tempat yang ramai diijamah warga bila liburan tiba ataupun hari-hari libur. Banyak pengunjung yang berdatangan dari dalam maupun luar desa, yang selalu tidak lupa mengabadikan kedatangan mereka dengan berfoto di dalam maupun luar komplek situs itu. Situs itu kini dipelihara oleh warga desa itu sendiri, yaitu Pak Sapran. Pak Sapran merupakan Juru Pelihara dari Dinas Kebudayaan Dan Pariwisata Provinsi Lampung. Saat ditemui, ia pun memberikan banyak informasi penting dari situs ini dimana batu berak ini terbuka untuk umum dan sampai sekarang, pengunjung tidak pernah dikenai pajak masuk atau semua-semua yang memberatkan bagi pengunjung situs. Meski begini, bila kita melihat ke semua area komplek situs ini, kebersihan hingga keasrian tetap terjaga. Peninggalan sejarah merupakan nilai sejarah yang perlu kita lestarikan. Dengan menjaga serta memelihara objek bersejarah berarti kita di ajarkan untuk menghargai peninggalan yang bernilai sejarah tentunya ini bukan hanya bagi peserta didik, tetapi juga masyarakat pada umumnya (Wawancara Pak Sapran pada tanggal 05 Juni 2018). Nilai sejarah yang dapat diambil dari Situs Batu Brak adalah menghargai situs-situs bersejarah baik dengan tidak merusak maupun turut serta merawat. Nilai sejarah yang dapat diambil adalah Situs Batu Brak dapat menggambarkan kehidupan masalalu tepatnya masa sebelum islam datang dengan masyarakat yang masih menganut anismisme. 


\section{Sumber Pembelajaran Sejarah}

Sumber belajar merupakan segala daya yang dapat dimanfaatkan oleh pendidik guna memberikan kemudahan bagi seseorang dalam belajarnya (Winataputra, Delfi, Pannen dan Mustafa dalam (Wijayanti, 2019 : 104). Sumber belajar sendiri menurut Association of Education Communication Technology (AECT) Tahun 1997 adalah semua sumber (data, manusia dan barang) yang dapat dipakai oleh pelajar sebagai suatu sumber tersendiri untuk memperlancar proses belajar yang melalui pesan, orang, material, alat, teknik dan lingkungan (Marwoto dalam Paramita, Patahuddin, \& Ridha, 2019 : 4).

Dalam mengidentifikasi sumber belajar, salah satunya adalah sumber belajar sejarah selain dituntut untuk penguasaan materi sejarah, juga dituntut untuk menguasai tentang materi kurikulum serta materi dan topik-topik pembelajaran yang berkaitan dengan lingkungan sekitar atau local wisdom sebagai sumber belajar sejarah (Nurmiyati, $2016: 93$ ).

Penggunaan situs sejarah lokal sebagai sumber belajar dapat dikatakan sebagai sesuatu yang berbeda, dimana dalam mengkaji situs yang bermuatan sejarah lokal akan lebih ditekankan pada pencapaian pengetahuan tentang peristiwa sejarah yang dijadikan sasaran studi yakni sejarah dari suatu lokalitas tertentu. Untuk itu penggunaan situs sejarah lokal sebagai sumber belajar di tingkat Universitas hendaknya dipandang sebagai salah satu alternatif yang mungkin dapat dipilih dan diterapkan dalam proses pembelajaran dengan menggunakan apa yang sering disebutkan sebagai living history, yakni sejarah dari lingkungan sekitar dirinya (Firdaus, 2019 : 67).

Situs Batu Brak dapat dijadikan sumber pembelajaran sejarah berbasis local wisdom, salah satu contohnya adalah dengan pembelajaran sejarah melalui kedatangan dan penyebaran masyarakat awal di Sumatra, khususnya Lampung. Kemampuan masyarakat pada masa pra aksara sudah mampu menghasilkan suatu benda yang artistik dan bernilai sesuai dengan manfaatnya. Peninggalan-peninggalan pada situs tersebut tentunya hadir dengan tujuan, manfaat dan pesan-pesan baik di dalamnya yang perlu dipelajari sebagai sumber sejarah. Mengingat dalam Sumber belajar sejarah sendiri sekarang banyak sumber - sumber belajar yang berkembang dan bervariasi, maka tentunya sumber belajar sejarah berbasis local wisdom sangat dapat membantu memudahkan peserta didik dalam memahami pembelajaran sejarah (Iwana \& Hanif, 2019:48).

Situs Batu Berak merupakan situs bersejarah yang memiliki berbagai nilai-nilai yang perlu diketahui, tidak hanya bagi peserta didik dan para pendidik, akan tetapi juga masyarakat luas harus mengetahuinya. Melalui pengetahuan sejarah berbasis sumber belajar local wisdom yang salah satunya adalah melalui Situs Batu Brak tentunya kita akan semakin bijak dalam hidup karena kita diajarkan akan nilai-nilai yang memang sangat sakral dan dijunjung tinggi oleh leluhur bangsa yang dapat dipelajari melalui Situs atau peninggalan - peninggalan yang berlokasi disekitar kita, seperti contohnya Situs Batu Brak. Peserta didik memiliki kewajiban tentunya mempelajari lebih jauh dan mendalam nilai-nilai sejarah apa saja yang terkandung di dalam peninggalan Situs Batu Brak.

Peserta didik dapat menjadikan Situs Batu Brak sebagai sumber pembelajaran sejarah berbasis local wisdom yang mempunyai nilai sejarah tinggi. Peserta didik dapat menjadikan media pembelajaran secara faktual bahwa bangsa indonesia adalah bangsa 
yang beradab dan maju. Peserta didik harus mengajarkan bahwa sejarah bukan sekedar dongeng atau cerita yang tak ada realitanya dalam kehidupan atau tidak dapat dibuktikan dengan fakta-fakta atau sumber - sumber data yang ada dan tergolong sumber primer. Nilai - nilai sejarah pada sebuah situs tidak semata - mata hanya mempelajari teori, namun dapat menjadi solusi yang ditawarkan untuk memperbaiki pendalaman materi serta dapat merangsang stimulus peserta didik dalam kegiatan belajar mengajar (Ayuningtyas, Hilmiah, \& Rohmawati, 2018 : 140).

Berbagai cara dapat dilakukan untuk memanfaatkan peninggalan bersejarah sebagai sumber pembelajaran sejarah, sebagai contohnya adalah dapat dilakukan dengan cara bentuk penugasan dengan bimbingan dosen. Khusus untuk mahasiswa sendiri dapat juga dilakukan dengan bentuk penungasan secara kelompok dengan mengunjungi situs cagar budaya yang lokasinya dekat dengan kampus (Pelealu, 2019 : 722). Pemanfaatan Nilai-nilai Situs Batu Berak sebagai sumber pembelajaran sejarah sendiri dapat dilakukan dengan cara penugasan secara berkelompok oleh dosen kepada mahasiswa, namun cara tersebut tentunya harus melalui beberapa syarat yang salah satunya adalah perencanaan pembelajaran yang relevan yakni contohnya adalah materi pada masa praaksara khususnya zaman batu

\section{Simpulan}

Situs Batu Berak merupakan situs peninggalan bersejarah, situs tersebut mempunyai fungsi sebagai tempat pemujaan, bukan tempat pemakaman pada zaman animisme. Situs ini telah mengalami pemugaran selama empat tahap, yang dimulai pada Tahun 1984 hingga 1989. Pada Tahun 1989, komplek Situs Batu Berak ini mulai dibuka untuk umum baik untuk wisata maupun untuk keperluan penelitian, khususnya penelitian sejarah. Situs Purbakala Batu Berak merupakan cagar budaya nasional yang di lindungi oleh Negara. Situs ini merupakan peninggalan pada masa zaman batu besar dan merupakan warisan budaya bagi masyarakat, khususnya masyarakat Lampung. Situs Batu Berak kaya akan Nilai- nilai sejarah yang dapat menjadi sumber pembelajaran sejarah bagi peserta didik, contohnya adalah mempelajari zaman batu masa animisme. Pemanfaatan Nilai-Nilai Sejarah Situs Batu Berak dapat menjadi solusi pendalaman materi serta dapat merangsang motivasi belajar peserta didik dalam proses kegiatan belajar mengajar.

\section{Daftar Pustaka}

Abdulah, T., Lapian, A. ., \& Dkk. (2012). Indonesia Dalam Arus Sejarah. Jakarta: Ichtiar Baru Van Hoeve.

Ayuningtyas, T. R., Hilmiah, A. S., \& Rohmawati, R. (2018). Pemanfaatan Situs Peninggalan Sejarah Di Kabupaten Bondowoso Sebagai Pengembangan Sumber Belajar Di Sekolah Lanjutan Tingkat Atas Di Kabupaten Bondowoso. Jurnal Historia, 6(1), 139-150.

Firdaus, D. W. (2019). Pemanfaatan Situs Astana Gede Sebagai Sumber Belajar Untuk Mengembangkan Kesadaran Sejarah Lokal Mahasiswa. Bihari: Pendidikan Sejarah Dan Ilmu Sejarah, 2(1), 63-76.

Iwana, N., \& Hanif, M. (2019). Kesenian Teledek Dalam Upacara Minta Hujan Di Lembeyan Magetan (Kajian Nilai Budaya Dan Potensinya Sebagai Sumber Belajar Sejarah). Gulawentah: Jurnal Studi Sosial, 4(1), 46-54. Https://Doi.Org/10.25273/Gulawentah.V4i1.5032

Kartodirjo, S. (1993). Pendekatan Ilmu Sosial Dalam Metodologi Sejarah. Jakarta: Gramedia.

Kartodirjo, S. (2014). Pendekatan Ilmu Sosial Dalam Metodologi Sejarah. Yogyakarta: Ombak. 
Nazir, M. (1998). Metode Penelitian Sosial. Jakarta: Ghalia Indonesia.

Nurmiyati. (2016). Peningkatan Kemampuan Guru Dalam Memanfaatkan Lingkungan Sekolah Sebagai Sumber Belajar Melalui Diskusi Kelompok Kerja Guru Di Sdn 1 Jenangan. Gulawentah: Jurnal Studi Sosial, 1(2), 91-102.

Paramita, A., Patahuddin, \& Ridha, H. R. (2019). Situs Jera' Lomp'e Sebagai Sumber Belajar Sejarah Siswa Kelas X Sman 8 Soppeng. Jurnal Pattingalloang, 6(3), 1-8.

Pelealu, A. E. (2019). Sumber Belajar Sejarah: Pemanfaatan Situs Cagar Budaya Di Minahasa. Seminar Nasional Sejarah Ke 4 Jurusan Pendidikan Sejarah Universitas Negeri Padang, 719-729.

Perdana, Y., Sumargono, \& Rachmedita, V. (2019). Integrasi Sosiokultural Siswa Dalam Pendidikan Multikultural Melalui Pembelajaran Sejarah. Jurnal Pendidikan Sejarah, 8(2), 79-98.

Prananda, M. N., Sarkadi, \& Ibrahim, N. (2018). Efektivitas Sumber Pembelajaran Sejarah. Jurnal Pendidikan Sejarah, 7(2), 67-84.

Siska, Y. (2017). Peninggalan Situs Megalitik Sekala Brak Dan Implikasinya Dalam Pembelajaran Sejarah Lokal Di Sekolah Dasar. Mimbar Sekolah Dasar, 4(2), 172-181. Https://Doi.Org/10.23819/Mimbar-Sd.V4i2.6489

Soedjatmoko, D. (1995). Historiografi Indonesia: Sebuah Pengantar. Jakarta: Gramedia Pustaka Utama.

Sri Ekwandari, Y., Perdana, Y., \& Lestari, N. I. (2020). Integrasi Pendidikan Multikultural Dalam Pembelajaran Sejarah Di Sma Yp Unila. Criksetra: Jurnal Pendidikan Sejarah, 9(1), 15-31.

Wasino. (2007). Dari Riset Hingga Tulisan Sejarah. Semarang: Unnes Press.

Wijayanti, N. (2019). Kesenian Tari Sufi: Studi Nilai Budaya Dan Potensinya Sebagai Sumber Pembelajaran Antropologi Di Man 1 Magetan. Gulawentah: Jurnal Studi Sosial, 4(2), 102-113. Https://Doi.Org/10.25273/Gulawentah.V4i2.5557 